International Journal of Industrial Engineering and Management (IJIEM), Vol. 9 No 4, 2018, pp. 229-243 Available online at www.iim.ftn.uns.ac.rs/ijiem_journal.php

ISSN 2217-2661

http://doi.org/10.24867/IJIEM-2018-4-229

\title{
Implementation Guidelines for Mass Customization: A Researcher-Oriented View
}

\author{
Nikola Suzić \\ Research Fellow, Department of Management and Engineering, University of Padova, Stradella S. Nicola, 3, \\ 36100 Vicenza, Italy, suzic@gest.unipd.it \\ Enrico Sandrin \\ Research Fellow, Department of Management and Engineering, University of Padova, Stradella S. Nicola, 3 , \\ 36100 Vicenza, Italy, enrico.sandrin@unipd.it
}

Svetlana Suzić

PhD Candidate, Department of Management and Engineering, University of Padova, Stradella S. Nicola, 3, 36100 Vicenza, Italy, svetlana.suzic@phd.unipd.it

Cipriano Forza

Full Professor, Department of Management and Engineering, University of Padova, Stradella S. Nicola, 3, 36100 Vicenza, Italy, cipriano.forza@unipd.it

\section{Alessio Trentin}

Assistant Professor, Department of Management and Engineering, University of Padova, Stradella S. Nicola, 3, 36100 Vicenza, Italy, alessio.trentin@unipd.it

\section{Zoran Anišić}

Full Professor, University of Novi Sad, Faculty of Technical Sciences, Trg Dositeja Obradovića 6, 21000 Novi Sad, Serbia, anisic@uns.ac.rs

Received (26.10.2018.); Revised (27.11.2018.); Accepted (03.12.2018.)

\begin{abstract}
Mass customization (MC) is gaining steady attention in both industry and academia. Recently, MC implementation guidelines (MC-IGs) have been identified as an emerging sub-stream of MC research. A review of this sub-stream has been published in the current year, with a practitioner-oriented view. The present paper complements that review by focusing on the researchers' need to improve the way $M C-I G s$ are developed and communicated. By providing data generated from a systematic literature review on MC-IGs, the present paper informs researchers about how much and in which way certain aspects of MC-IGs have been considered in the available guidelines. Through a systematic and detailed description of the published MC-IGs, the present article supports researchers to clearly communicate the similarities and differences in their proposed advancements on MC-IGs. Finally, by reflecting on the very nature of the output of $M C$-IG research, this article suggests open and wide adoption of the design science research strategy to develop and test MC-IGs.
\end{abstract}

Key words: mass customization, implementation guidelines, literature review, product platform, modularity, group technology, part standardization, form postponement, concurrent product-processsupply chain engineering, product configuration, design science research

\section{INTRODUCTION}

Mass customization (MC), that is, the organization's ability to provide customized products and services that fulfil each customer's idiosyncratic needs without considerable trade-offs in cost, delivery, and quality, [1$5]$, is gaining steady attention in both industry and academia [1, 2, 6-9]. Various technology- and organization-based factors enable the development of MC capabilities $[1,6,10]$. The choice and coherent implementation of these enablers are not at all easy; however, they can be facilitated by MC implementation guidelines (MC-IGs) [1]. These guidelines are "intended to guide company transformation towards $\mathrm{MC}[\ldots]$ by providing: An overview of MC; The applicability context of the IGs; As-is analysis tools to assess the company's current situation; Exemplified implementation instructions of MC enablers; Required resources for implementation of MC enablers; [and] Factors that may hinder implementation of MC enablers" [1, p.864].

Several MC-IGs, published in many different journals, are available in the literature [1]. Altogether, they can be considered an emerging $\mathrm{MC}$ research sub-stream [1]. Recently, Suzić et al. [1] performed a systematic review of the MC-IGs published in academic journals, adopting the point of view of practitioners. They compared and summarized the indications provided by different MC 
guidelines and provided several indications on the characteristics MC-IGs should have to better satisfy the needs of managers who embrace MC implementation. Unfortunately, in their extended practitioners-oriented article there was not enough space to provide researchers detailed indications regarding how MC-IGs are developed, tested, and communicated.

The present article complements the research reported in Suzić et al. [1] to provide MC-IG researchers specific support regarding modalities to develop, test, and communicate new MC-IGs. More specifically, the present researcher-oriented article reports detailed data on the available MC-IGs, generated from the Suzić et al.'s [1] systematic literature review but not fully included in the resulting article [1], and presents new considerations to improve how MC-IGs are developed, tested, and communicated. The reported data inform researchers about how much specific aspects of MC-IGs have been considered and the way they have been presented. This detailed information supports researchers in deciding how to position their work with respect to previous MC-IGs. Hopefully, this support will facilitate researchers in valuing their research results when they have to communicate their findings and clearly state their specific contribution. Furthermore, by realizing that $\mathrm{MC}-\mathrm{IG}$ research is aimed to develop solutions and not to explain phenomena, the present article provides researchers a research strategy that can raise the quality and the status of MC-IG research.

The rest of this article is organized in 4 sections, namely: Literature review method, Results of MC implementation guidelines analysis, Discussion, and Conclusions. The "Literature review method" section provides fully detailed information on the search and selection strategy, the coding process, and the coding criteria. The "Results of MC implementation guidelines analysis" section provides a very detailed quantitative description of the results. The "Discussion" section indicates opportunities to improve the presentation of future MC-IGs as well as the adopted research strategy and discusses the contribution of the present article in comparison to published MC literature reviews. The "Conclusions" section sums up the contributions and limitations of the present article and its implications for future MC-IG research.

\section{LITERATURE REVIEW METHOD}

A literature review is usually used for summarizing the state of the art in the subject field of interest and for identifying future research opportunities [11]. In order to secure the replicability of the research, we set out to clearly define the research method [11-13]. Thus, in the remainder of this section, we present in detail the search strategy, article selection process, coding criteria, and coding process applied.

\subsection{Search strategy and article selection}

We focused our literature review on IGs available in academic literature that introduce MC starting from the current (as-is) situation of a company. Replicating the search strategy of Fogliatto, da Silveira, and Borenstein [8], we used the terms "mass customization"/"mass customisation" in order to concentrate on papers dealing with MC. In addition, in order to focus on notions of "implementation guidelines" or "implementation methodology," these two search terms were combined (by using the AND operator) with at least one of the following terms (i.e., by using any of the following terms connected with the OR operator): "implementation," "methodology," "mov" (moving towards, etc.), "enabl*" (enabler, enabling, enable, etc.), "adopt" (adoption, adopt, etc.), "obstacl*" (obstacle, obstacles, etc.) or "guid" (guide, guidelines, etc.). The use of these keywords to search for IGs is based on the synonymous way the terms "implementation guidelines" and/or "implementation methodology" are used in the management literature dealing with implementation (cf. $[14,15])$.

The search was conducted on Article Title, Abstract, and Keywords in the Scopus database, encompassing articles published up to March 2015. Conference papers, conference reviews, books, and book chapters were excluded from the search. This choice follows the motivation provided by Fogliatto, da Silveira, and Borenstein [8], who asserted that the field of $M C$ research is mature enough to allow searches for significant research contributions in articles only. Furthermore, only publications in the English language were taken into account. Using these search criteria, the initial search yielded 549 articles (Table 1).

These 549 articles were further selected based on the quality of the journal in which they were published. A journal and its publications were taken into account only if all subject categories in which the journal was classified in the Scimago database were ranked Q1 or Q2 in the Scimago rankings for the year 2013. This criterion led to a total of 387 publications published in 145 journals.

A number of these 387 articles are not really intended to guide MC implementation in practice (some of them are review articles, some deal with $\mathrm{MC}$ enabler typologies, etc.). Thus, we developed a set of 3 criteria to further refine our article selection ([1], Table 1).

After the criteria were established, we were able to further narrow the selection of the articles. We read the abstracts and applied criterion 1, in this way excluding articles that are not intended to guide $\mathrm{MC}$ implementation in practice. A conservative approach was applied in the selection process, bringing the articles for which a clear decision could not be made in this step to the next selection step. This meant that criterion 1 also had to be applied in the next step. In effect, 235 articles passed the abstract reading.

Among the 235 articles, some deal with several MC enablers, while others deal with only one $M C$ enabler. Mass customization implementation guidelines should consider multiple MC enablers [1, 6, 8, 16-25] and should use a holistic approach to MC implementation [1, $16,24,26,27]$. Thus, in the present research, we do not regard articles that cover single $\mathrm{MC}$ enablers as $\mathrm{MC}-\mathrm{IGs}$. As a result, we further selected articles based on the shared belief that, in order to achieve MC, two or more MC enablers should be implemented (criteria 2 and 3 ). We further read the full text of the 235 articles using criteria 2 and 3 in combination with criterion 1, and finally ended up with 20 relevant articles. 
Table 1. Article search and selection steps

\begin{tabular}{|c|c|c|c|}
\hline Step & $\begin{array}{c}\text { Search/ } \\
\text { selection step }\end{array}$ & Criteria used & $\begin{array}{l}\text { Resulting } \\
\text { number of } \\
\text { articles }\end{array}$ \\
\hline 1 & Initial search & 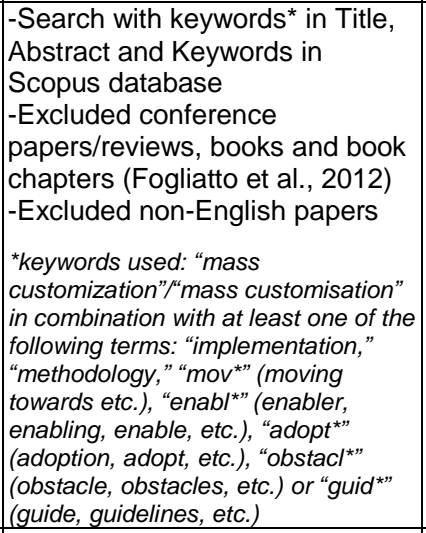 & 549 \\
\hline 2 & $\begin{array}{l}\text { Publication } \\
\text { quality } \\
\text { selection }\end{array}$ & $\begin{array}{l}\text { Selection based on journal } \\
\text { ranking (keeping articles from } \\
\text { Q1 and Q2 journals in the } \\
\text { Scimago database) }\end{array}$ & 387 \\
\hline 3 & $\begin{array}{l}\text { Abstract } \\
\text { reading }\end{array}$ & $\begin{array}{l}\text { Criterion } 1 \text { Article states the } \\
\text { objective of developing MC-IGs } \\
\text { or claims to contribute to guiding } \\
\text { the implementation of MC }\end{array}$ & 235 \\
\hline 4 & $\begin{array}{l}\text { Full text } \\
\text { reading }\end{array}$ & \begin{tabular}{|l|} 
Criterion 1 \\
AND \\
(Criterion 2 Article provides \\
information about the order in \\
which two or more MC \\
enablers should be \\
implemented \\
OR \\
Criterion 3 Article provides \\
implementation instructions for \\
each of two or more MC \\
enablers, regardless of \\
whether or not it fulfils \\
Criterion 2)
\end{tabular} & 20 \\
\hline
\end{tabular}

Table 1 shows the overview of the article search and selection process, which is exactly the same as that adopted by Suzić et al. [1].

This emerging $M C$ research sub-stream (i.e., half of the articles published in the five-year period of 2010-2015) is highly dispersed across 17 journals (Table 2). There is also a notable prevalence of engineering and industrial engineering journals among the sources (Table 2).

\subsection{Coding process and coding criteria}

We opted to build our classification scheme in an inductive manner [28], since our MC literature search did not reveal a research framework suitable for conducting deductive analysis of the relevant articles. Inductive analysis "refers to approaches that primarily use detailed readings of raw data to derive concepts, themes, or a model through interpretations made from the raw data by an evaluator or researcher," with a primary purpose "to allow research findings to emerge from the frequent, dominant, or significant themes inherent in raw data, without the restraints imposed by structured methodologies" [28, p.238]. This absence of preconceptions in the analysis of scientific contributions is one of the reasons why in recent years inductive analysis has been gaining significance as a data analysis strategy in systematic literature reviews [29-33].
Table 2. Journal overview with articles

\begin{tabular}{|c|c|c|}
\hline Journal name & $\begin{array}{l}\text { No. of relevant } \\
\text { articles per } \\
\text { journal }\end{array}$ & Article/s \\
\hline $\begin{array}{l}\text { International Journal of } \\
\text { Computer Integrated } \\
\text { Manufacturing }\end{array}$ & 3 & {$[24,34,35]$} \\
\hline $\begin{array}{l}\text { Open Construction \& Building } \\
\text { Technology Journal }\end{array}$ & 2 & {$[36,37]$} \\
\hline $\begin{array}{l}\text { Al EDAM: Artificial } \\
\text { Intelligence for Engineering } \\
\text { Design, Analysis and } \\
\text { Manufacturing }\end{array}$ & 1 & [38] \\
\hline Business Horizons & 1 & [39] \\
\hline $\begin{array}{l}\text { Concurrent Engineering: } \\
\text { Research and Applications }\end{array}$ & 1 & [40] \\
\hline Engineering Optimization & 1 & [20] \\
\hline $\begin{array}{l}\text { IEEE Transactions on } \\
\text { Engineering Management }\end{array}$ & 1 & [41] \\
\hline $\begin{array}{l}\text { IIE Transactions (Institute of } \\
\text { Industrial Engineers) }\end{array}$ & 1 & [42] \\
\hline $\begin{array}{l}\text { International Journal of } \\
\text { Production Research }\end{array}$ & 1 & [43] \\
\hline $\begin{array}{l}\text { International Journal on } \\
\text { Interactive Design and } \\
\text { Manufacturing }\end{array}$ & 1 & [44] \\
\hline $\begin{array}{l}\text { Journal of Intelligent } \\
\text { Manufacturing }\end{array}$ & 1 & [45] \\
\hline Journal of Mechanical Design & 1 & [46] \\
\hline $\begin{array}{l}\text { Journal of Mechanical } \\
\text { Engineering - Strojniski } \\
\text { vestnik }\end{array}$ & 1 & [47] \\
\hline $\begin{array}{l}\text { Journal of Systems and } \\
\text { Software }\end{array}$ & 1 & [48] \\
\hline Management Decision & 1 & [22] \\
\hline $\begin{array}{l}\text { Research in Engineering } \\
\text { Design }\end{array}$ & 1 & [49] \\
\hline $\begin{array}{l}\text { The International Journal of } \\
\text { Advanced Manufacturing } \\
\text { Technology }\end{array}$ & 1 & [50] \\
\hline Total & 20 & \\
\hline
\end{tabular}

Table 3. The steps of the inductive analysis coding process (based on [28] and [51])

\begin{tabular}{|c|c|c|c|}
\hline $\begin{array}{l}\text { Phase } \\
\text { number }\end{array}$ & \begin{tabular}{|} 
Phases of the \\
inductive \\
analysis coding \\
process \\
(based on [28] \\
and [51])
\end{tabular} & $\begin{array}{l}\text { Description of the } \\
\text { coding phase }\end{array}$ & $\begin{array}{l}\text { Resulting } \\
\text { number of } \\
\text { categories }\end{array}$ \\
\hline 1 & $\begin{array}{l}\text { Initial reading of } \\
\text { text data }\end{array}$ & $\begin{array}{l}\text { Initial reading of the } \\
\text { relevant articles (done } \\
\text { in the selection } \\
\text { process) }\end{array}$ & $\begin{array}{l}\text { Categories not } \\
\text { yet defined }\end{array}$ \\
\hline 2 & $\begin{array}{l}\text { Identify specific } \\
\text { text segments } \\
\text { related to } \\
\text { objectives }\end{array}$ & $\begin{array}{l}\text { Initial identification of } \\
\text { text segments dealing } \\
\text { with MC-IGs }\end{array}$ & $\begin{array}{l}\text { Multiple } \\
\text { potential } \\
\text { categories }\end{array}$ \\
\hline 3 & $\begin{array}{l}\text { Label the } \\
\text { segments of } \\
\text { text to create } \\
\text { categories }\end{array}$ & $\begin{array}{l}\text { Creation and } \\
\text { application of a } \\
\text { tentative classification } \\
\text { scheme }\end{array}$ & 123 \\
\hline 4 & $\begin{array}{l}\text { Reduce overlap } \\
\text { and } \\
\text { redundancy } \\
\text { among } \\
\text { categories }\end{array}$ & $\begin{array}{l}\text { Iterative refinement of } \\
\text { the tentative } \\
\text { classification scheme } \\
\text { through discussion in } \\
\text { research team }\end{array}$ & \begin{tabular}{l}
\multicolumn{1}{c}{57} \\
(16 coding \\
dimensions/sub- \\
dimensions and \\
41 codes/sub- \\
codes)
\end{tabular} \\
\hline 5 & $\begin{array}{l}\text { Create a model } \\
\text { incorporating } \\
\text { the most } \\
\text { important } \\
\text { categories }\end{array}$ & $\begin{array}{l}\text { Deriving MC-IG } \\
\text { building blocks by } \\
\text { marking out the subset } \\
\text { of coding dimensions } \\
\text { that directly address } \\
\text { the content of MC-IGs }\end{array}$ & $\begin{array}{l}\quad 7 \\
\text { (MC-IG building } \\
\text { blocks) }\end{array}$ \\
\hline
\end{tabular}


The inductive coding process consisted of 5 phases (Table 3), during which, articles were read several times in order to identify themes and categories (coding dimensions and codes). After the initial identification of specific relevant text segments (phases 1 and 2, Table 3 ), the text segments were labelled and a provisional classification scheme was created and applied to the articles (phase 3, Table 3). Next, the tentative scheme was iteratively refined based on group discussions, and the articles were re-classified (phase 4 , Table 3). This iterative process continued until complete agreement was reached among the researchers. After the final classification of the articles, the MC-IG building blocks were identified by marking out the subset of coding dimensions that directly address the content of MC-IGs (phase 5, Table 3).

In order to enhance the readability and communication of the present article, we provide the main definitions of the coding dimensions/sub-dimensions (phase 4, Table 3) in Table 4. These definitions are taken from the previous part of the research reported in Suzić et al. [1]. Moreover, in order to make the inductive approach more transparent, hereafter we provide further details on part of the process. Specifically, we describe the identification of the coding dimension and codes for the "applicability context of the guidelines" (Table 5). The applicability context of the guidelines (dim. 3, Table 5) is reported in a number of articles, but in some articles, the applicability context is stated and its validity is justified with a clear explanation (dim. 2-code 1, Table 5), while other articles simply state the applicability context without explaining why this context is valid for the presented MC-IGs (dim. 3-code 2, Table 5). Further, some articles simply presume that the applicability context is self-evident, since, for example, all of the examples the article provides are related to one industry or product type (dim. 3-code 3, Table 5). In the end, some articles did not provide even a hint of the applicability context (dim. 3code 4 , Table 5). In order to avoid redundancy, coding dimensions as well as their codes will be defined and further explained in the Results section.

\section{RESULTS OF THE MC IMPLEMENTATION GUIDELINES ANALYSIS}

The 20 selected articles were analyzed carefully via full-text reading. They were classified based on (1) MC overview, (2) MC implementation instructions, (3) applicability context of the guidelines, (4) required resources, (5) as-is analysis tools, (6) hindrance factors, (7) instruction exemplification, (8) instruction format, and (9) research method.

\subsection{Mass customization overview}

The analysis of available MC-IGs shows that:

- Only $20 \%$ of articles provide an overview of MC (Table 6);

- Articles differ substantially regarding the provided MC overviews:

- some articles cover a wide range of MC overview components (e.g., [24, 45]); while

- other articles address only a few MC overview components.
Table 4. Definitions of the main coding dimensions/subdimensions (All definitions reported in the table are quotes taken from Suzić et al. [1, p.859])

\begin{tabular}{|c|c|}
\hline No. & $\begin{array}{l}\text { Definition of the main coding dimension/sub- } \\
\text { dimension }\end{array}$ \\
\hline 1 & $\begin{array}{l}\text { MC overview presents the essentials of the MC concept. } \\
\text { These essentials include a definition of } M C \text {, a list of } M C \\
\text { enablers, definitions of } M C \text { enablers, a set of the basic } M C \\
\text { enabler relationships, a list of the company departments } \\
\text { involved in implementing } M C \text {, a set of the benefits derived } \\
\text { from MC implementation and a set of the benefits derived } \\
\text { from each MC enabler implementation. The MC definition } \\
\text { and the list of MC enablers together comprise a minimum } \\
M C \text { overview. }\end{array}$ \\
\hline 2 & $\begin{array}{l}\text { MC implementation instructions describe how to implement } \\
\text { MC. They indicate which MC enablers to implement and } \\
\text { the steps to implement them. MC implementation } \\
\text { instructions can be classified into two types: } \\
\text { (1) "Single enabler" implementation instructions } \\
\text { (2) "Bundled enabler" implementation instructions }\end{array}$ \\
\hline 2.1 & $\begin{array}{l}\text { "Single enabler" implementation instructions are presented } \\
\text { as guidance to implement one specific MC enabler in } \\
\text { practice. }\end{array}$ \\
\hline 2.2 & $\begin{array}{l}\text { "Bundled enabler" implementation instructions are } \\
\text { implementation instructions that define relationships } \\
\text { between two or more enablers. The relationship can be one } \\
\text { of precedence, embeddedness or parallel implementation. } \\
\text { While "single enabler" implementation instructions aim to } \\
\text { provide detailed implementation instructions for one } \\
\text { specific enabler, "bundled enabler" implementation } \\
\text { instructions aim to define the relationships between two or } \\
\text { more enablers. }\end{array}$ \\
\hline 3 & $\begin{array}{l}\text { The applicability context of the guidelines concerns the } \\
\text { generali[z]ability of the MC-IGs. The applicability context } \\
\text { provides the limits of validity for the proposed guidelines. } \\
\text { For example, the industry, types of products and size of the } \\
\text { company represent the applicability context of the } \\
\text { guidelines. }\end{array}$ \\
\hline 4 & $\begin{array}{l}\text { Required resources are the resources needed to } \\
\text { implement } \mathrm{MC} \text { or one or more } \mathrm{MC} \text { enablers. Some } \\
\text { examples of required resources are financial resources, } \\
\text { time, human resources and other resources required for } \\
\mathrm{MC} \text { implementation. }\end{array}$ \\
\hline 5 & $\begin{array}{l}\text { As-is analysis tools support assessments of the current } \\
\text { company situation concerning future MC implementation } \\
\text { challenges. They can be in the form of procedures, } \\
\text { formulae, templates and so on. }\end{array}$ \\
\hline 6 & $\begin{array}{l}\text { Hindrance factors are variables that negatively affect MC } \\
\text { implementation. They can appear in the form of resistance } \\
\text { to change as well as various other obstacles, challenges, } \\
\text { barriers, and so on. }\end{array}$ \\
\hline 7 & $\begin{array}{l}\text { Instruction exemplification refers to providing an example } \\
\text { of an implementation instruction's application. The } \\
\text { example aims to show how an application of the } \\
\text { implementation instruction would look in practice. }\end{array}$ \\
\hline 8 & $\begin{array}{l}\text { Instruction format refers to the way implementation } \\
\text { instructions are organized and presented. Depending on } \\
\text { the instruction format, implementation instructions can be } \\
\text { more or less well organized and presented. }\end{array}$ \\
\hline 9 & $\begin{array}{l}\text { The research method is an important characteristic of a } \\
\text { scientific contribution and is even more important in the } \\
\text { case of an applied discipline where the research addresses } \\
\text { both academics and practitioners. }\end{array}$ \\
\hline
\end{tabular}

- A definition of MC is provided in $65 \%$ of MC-IGs. Moreover, most of the MC-IGs (54\%) refer to Pine's definition of MC [3].

- Some MC enabler definitions are provided in $90 \%$ of the MC-IGs. Usually, these definitions are limited to the MC enablers that fall within the article's scope of the article proposing the MC-IGs. 
Table 5. Coding dimensions with codes

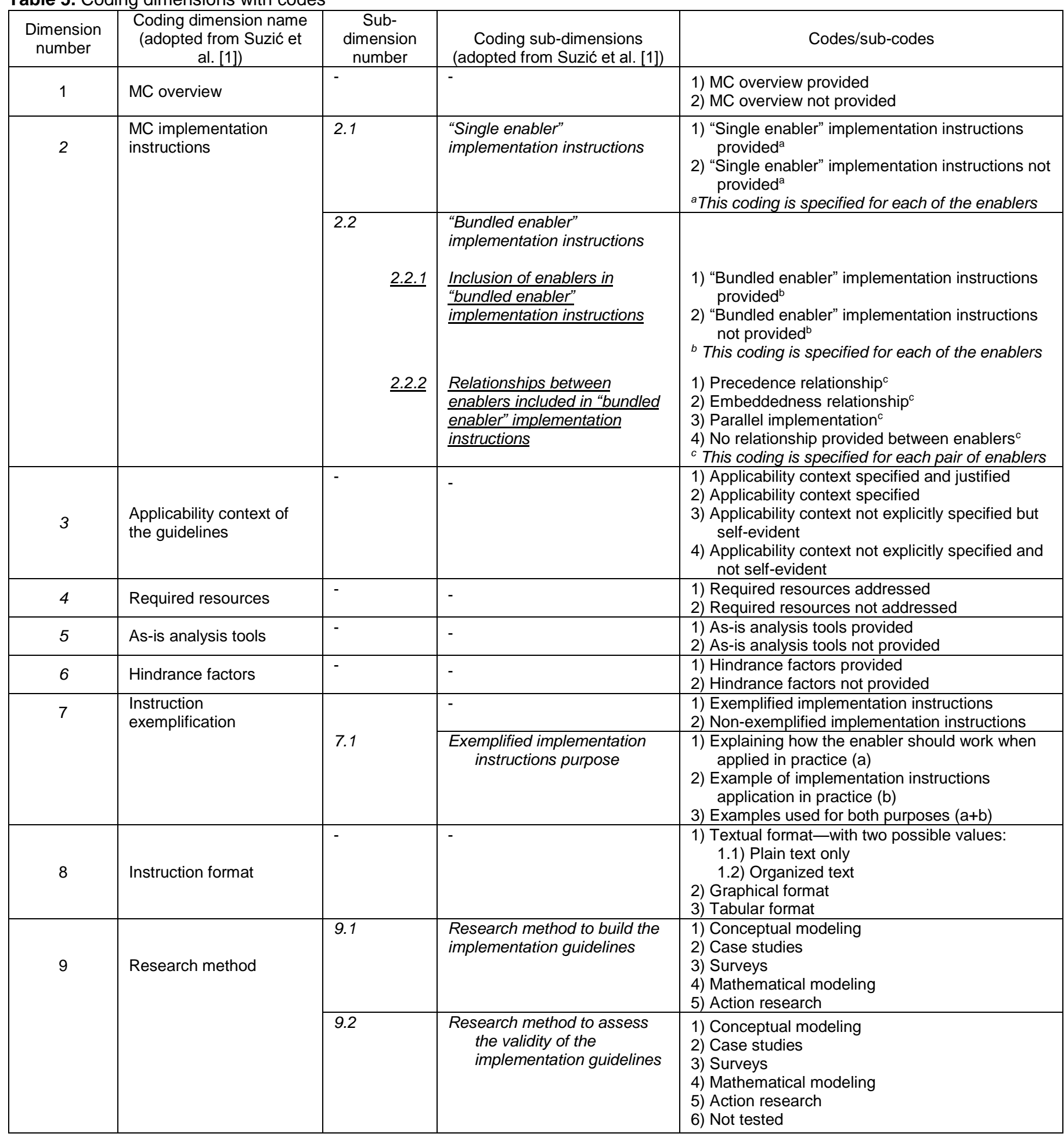

\subsection{MC implementation instructions}

MC implementation instructions can be classified into two types depending on their scope (defined in Table 4):

(1) "single enabler" implementation instructions; and

(2) "bundled enabler" implementation instructions.

Enablers considered in the implementation instructions. Eight enablers are considered in the "single enabler" and/or the "bundled enabler" implementation instructions in the articles (Table 7), namely: group technology, part standardization, product modularization, process modularity, product platform development, information technology (IT)-based product configuration, form postponement, and concurrent product-process-supply chain engineering. For definitions of MC enablers, please refer to Suzić et al. [1].

The analysis of available MC implementation guidelines shows that: 
- There are $7 \mathrm{MC}$ enablers for which at least 1 article provides "single enabler" implementation instructions (Table 7).

- The enablers for which "single enabler" implementation instructions are most frequently provided are product platform development and product modularization (14 articles, Table 7); part standardization and IT-based product configuration are present in 6 and 7 articles, respectively; while the least considered enablers are group technology (3 articles), form postponement (2 articles) and concurrent product-process-supply chain engineering for $\mathrm{MC}$ ( 1 article).

- The number of enablers for which "single enabler" implementation instructions are provided varies considerably across articles (Table 8).

- In most cases (75\% of articles), these instructions are provided for 2 or 3 enablers per article (Table 8).

- "Single enabler" implementation instructions may or may not include the sequence of activities, that is, the constraint-driven order of the activities needed to implement one MC enabler. In order to be treated as a sequence, at least one constraint must be explicitly stated between the start and finish of the different MC implementation activities. An analysis of the articles that include "single enabler" implementation instructions shows that $43 \%$ of the cases provided the sequence of activities to be done during the implementation of the enabler.

- "Bundled enabler" implementation instructions are provided in all 20 articles (Table 9). Notably, the selection criteria allowed the retention of articles that do not explicitly provide "bundled enabler" implementation instructions. However, a careful reading of these articles revealed the presence of implicit "bundled enabler" implementation instructions. Thus, these instructions were also categorized according to the degree of explicitness of the presentation of the implementation relationships among the $\mathrm{MC}$ enablers (Table 9). As a result, most "bundled enabler" implementation instructions are provided for 3 enablers (9 articles) or 2 enablers ( 8 articles) and are explicitly provided in 14 articles $(70 \%$, Table 9$)$.

- "Bundled enabler" implementation instructions can refer to different relationships between enablers [1], namely:

- precedence relationship - "when IGs state that one enabler should be implemented before the other enabler" [1, p.858]. For example, instructions can state that part standardization must precede product modularization in the implementation process;

- embeddedness relationship - "when IGs state that the implementation of one enabler is a part of another enabler's implementation" [1, p.858]. For example, implementation guidelines could indicate that product modularization is not an independent enabler but is part of (embedded in) product platform development; and
Table 6. Summary of the articles, classified according to MC overview

\begin{tabular}{|c|c|c|c|}
\hline $\begin{array}{c}\text { Coding } \\
\text { dimension }\end{array}$ & Codes & $\begin{array}{c}\text { Number } \\
\text { of articles }\end{array}$ & $\begin{array}{c}\text { Percent } \\
\text { of articles }\end{array}$ \\
\hline \multirow{2}{*}{ MC overview } & MC overview provided & 4 & $20 \%$ \\
\cline { 2 - 4 } & MC overview not provided & 16 & $80 \%$ \\
\hline \multicolumn{2}{r|}{ Total number of articles } & 20 & $100 \%$ \\
\hline
\end{tabular}

Table 7. The list of enablers used in the articles, with frequency of appearance (based on "single enabler" implementation instructions provided)

\begin{tabular}{|l|c|c|}
\hline Enabler name & $\begin{array}{c}\text { Number of articles } \\
\text { in which "single } \\
\text { enabler" } \\
\text { implementation } \\
\text { instructions are } \\
\text { provided }\end{array}$ & $\begin{array}{c}\text { Percent of articles } \\
\text { in which "single } \\
\text { enabler" } \\
\text { implementation } \\
\text { instructions are } \\
\text { provided }\end{array}$ \\
\hline $\begin{array}{l}\text { Product platform } \\
\text { development }\end{array}$ & 14 & $70 \%$ \\
\hline $\begin{array}{l}\text { Product } \\
\text { modularization }\end{array}$ & 14 & $70 \%$ \\
\hline Part standardization & 7 & $35 \%$ \\
\hline $\begin{array}{l}\text { IT-based product } \\
\text { configuration }\end{array}$ & 6 & $30 \%$ \\
\hline Group technology & 3 & $15 \%$ \\
\hline Form postponement & 2 & $10 \%$ \\
\hline $\begin{array}{l}\text { Concurrent product- } \\
\text { process-supply } \\
\text { chain engineering }\end{array}$ & 1 & $5 \%$ \\
\hline Process modularity & 0 & $0 \%$ \\
\hline
\end{tabular}

Table 8. Summary of the articles classified according to "single enabler" implementation instructions

\begin{tabular}{|c|c|c|c|c|}
\hline Coding dimension & Codes & $\begin{array}{l}\text { Count per } \\
\text { article }\end{array}$ & \begin{tabular}{|l|} 
Number \\
of articles
\end{tabular} & \begin{tabular}{|} 
Percent \\
of \\
articles
\end{tabular} \\
\hline \multirow{7}{*}{$\begin{array}{l}\text { "Single enabler" } \\
\text { implementation } \\
\text { instructions }\end{array}$} & \multirow{6}{*}{$\begin{array}{l}\text { "Single enabler” } \\
\text { implementation } \\
\text { instructions } \\
\text { provided for... }\end{array}$} & $\begin{array}{l}6 \text { or more } \\
\text { enablers }\end{array}$ & 0 & $0 \%$ \\
\hline & & 5 enablers & 1 & $5 \%$ \\
\hline & & 4 enablers & 1 & $5 \%$ \\
\hline & & 3 enablers & 6 & $30 \%$ \\
\hline & & 2 enablers & 9 & $45 \%$ \\
\hline & & 1 enabler & 2 & $10 \%$ \\
\hline & $\begin{array}{l}\text { "Single enabler" } \\
\text { implementation } \\
\text { instructions not } \\
\text { provided }\end{array}$ & \begin{tabular}{|l}
...not \\
provided
\end{tabular} & 1 & $5 \%$ \\
\hline \multicolumn{3}{|r|}{ of articles } & 20 & $100 \%$ \\
\hline
\end{tabular}

Table 9. Summary of the articles classified according to inclusion of enablers in "bundled enabler" implementation instructions

\begin{tabular}{|c|c|c|c|c|c|c|}
\hline \multirow[t]{2}{*}{$\begin{array}{l}\text { Coding sub- } \\
\text { dimension }\end{array}$} & \multirow[t]{2}{*}{ Codes } & \multirow[t]{2}{*}{ Count per article } & \multicolumn{3}{|c|}{\begin{tabular}{|c|} 
Way of \\
presenting \\
the \\
relationships \\
in the article
\end{tabular}} & \multirow[t]{2}{*}{$\begin{array}{c}\text { No. of } \\
\text { articles } \\
\text { (percent) }\end{array}$} \\
\hline & & & $E^{*}$ & & $E / I$ & \\
\hline \multirow{6}{*}{$\begin{array}{l}\text { Inclusion of } \\
\text { enablers in } \\
\text { "bundled } \\
\text { enabler" } \\
\text { implementa- } \\
\text { tion } \\
\text { instructions }\end{array}$} & \multirow{5}{*}{$\begin{array}{l}\text { "Bundled } \\
\text { enabler" } \\
\text { implementa- } \\
\text { tion } \\
\text { instructions } \\
\text { provided }\end{array}$} & 6 related enablers & 1 & 0 & 0 & $1(5 \%)$ \\
\hline & & 5 related enablers & 0 & 1 & 1 & $2(10 \%)$ \\
\hline & & 4 related enablers & 0 & 0 & 0 & $0(0 \%)$ \\
\hline & & 3 related enablers & 6 & 2 & 1 & $9(45 \%)$ \\
\hline & & 2 related enablers & 7 & 1 & 0 & $8(40 \%)$ \\
\hline & \begin{tabular}{|l|} 
"Bundled \\
enabler" \\
implementa- \\
tion \\
instructions \\
not provided \\
\end{tabular} & $\begin{array}{c}\text { No related } \\
\text { enablers }\end{array}$ & $\underset{* *}{N}$ & $\mathrm{~N}$ & $\mathrm{~N}$ & $0(0 \%)$ \\
\hline \multicolumn{3}{|c|}{ Total number of articles } & 14 & 4 & 2 & $\begin{array}{c}20 \\
(100 \%)\end{array}$ \\
\hline
\end{tabular}
not applicable 
- parallel implementation - "when IGs state that one enabler should be implemented at the same time as another enabler" [1, p.858]. For example, instructions can state that form postponement should be implemented at the same time as product platforms are developed.

- A detailed analysis of enabler relationships available in the MC-IGs shows that precedence relationships, that is, the sequential logic, dominate the resulting relationships model [1]. Specifically: group technology should be implemented before product platform development; product platform development embeds both part standardization and product modularization; part standardization should be implemented before product modularization; and product platform development should be implemented before IT-based product configuration [1]. However, a detailed analysis of enabler relationships is beyond the scope of this paper. Thus, for a detailed analysis and explanation of enabler relationships, please refer to Suzić et al. [1].

- The number of enablers for which "single enabler" implementation instructions are provided per article (usually 2 or 3 , Table 8 ) and the number of enablers that are related through 'bundled enabler' implementation instructions per article (usually 2 or 3 , Table 9 ) is relatively small, bearing in mind that, in total, 8 different enablers were recorded in the articles reviewed in the present study (Table 7).

\subsection{Applicability context of the guidelines}

The analysis of available MC-IGs shows that:

- Only $35 \%$ of the articles explicitly cover the applicability context dimension (first two codes in Table 10), which shows that generalizability tends not to be discussed explicitly in the articles.

- Only 2 articles that address the generalizability issue were found. Kudsk, Hvam et al. [37] indicated generalizability by stressing similarities between the building construction industry and the cement factory design/construction sector, while Ismail et al. [41] based their applicability context on a widely recognized characteristic of SMEs: the lack of resources.

- Most of the articles deal with manufacturing (90\%).

- Only $5 \%$ of articles deal with services.

- The articles that deal with manufacturing mostly address mechanical production, electronics, and construction (e.g., complex products such as cars, industrial steam turbines, computers, etc.).

- Country and market are not addressed as applicability contexts in the articles.

\subsection{Required resources}

The analysis of available MC-IGs shows that:

- Only $20 \%$ of the articles address required resources (Table 11).

- When addressed, the resources required to implement MC are often addressed without specifying the resource type. For example, [48, p.104] stated that "significant efforts" are needed for optimizing a software product platform.

- Usually, when resources are addressed, only a single resource is addressed per article.

- The types of resources addressed are:

- financial resources (e.g., cost of a product configurator through an estimated "cost of the software" based on prior experiences in $\mathrm{MC}$ implementation [37, p.96]; and "additional costs for developing a new platform" [46, p.5]); and

- human resources (e.g., training of personnel to assemble certain platform type [35, p.1003]; and human resources for developing a configuration system, that is, "it was deemed necessary to use four man years to develop the system" [37, p.96]).

- The set of required resources addressed is usually limited to the scope of the article and includes, at the most, those resources required for implementing the one or two MC enablers considered in the article, usually not taking into account the overall implementation of MC.

\subsection{As-is analysis tools}

The analysis of available MC-IGs shows that:

- $25 \%$ of the articles include as-is analysis tools (Table 12).

- As-is analysis tools do not go beyond the scope of the MC enablers addressed in the article, and as-is analysis tools are used:

- as part of the methodology for the development of product family architecture for MC [45];

- for enabling implementation of IT-based product configuration [36, 37];

Table 10. Summary of the articles classified according to applicability context of the guidelines

\begin{tabular}{|c|l|c|c|}
\hline \multirow{2}{*}{$\begin{array}{c}\text { Coding } \\
\text { dimension }\end{array}$} & Codes & $\begin{array}{c}\text { Number } \\
\text { of } \\
\text { articles }\end{array}$ & $\begin{array}{c}\text { Percent } \\
\text { of } \\
\text { articles }\end{array}$ \\
\hline \multirow{2}{*}{$\begin{array}{c}\text { Applicability } \\
\text { context of the } \\
\text { guidelines }\end{array}$} & $\begin{array}{l}\text { Applicability context specified and } \\
\text { justified }\end{array}$ & 2 & $10 \%$ \\
\cline { 2 - 4 } & $\begin{array}{l}\text { Applicability context specified } \\
\text { specified but self-evident }\end{array}$ & 5 & $25 \%$ \\
\cline { 2 - 4 } & $\begin{array}{l}\text { Applicability context not explicitly } \\
\text { specified and not self-evident }\end{array}$ & 1 & $5 \%$ \\
\hline \multicolumn{2}{|r|}{ Total number of articles } & 20 & $100 \%$ \\
\hline
\end{tabular}

Table 11. Summary of the articles classified according to required resources

\begin{tabular}{|c|c|c|c|}
\hline $\begin{array}{c}\text { Coding } \\
\text { dimension }\end{array}$ & Codes & $\begin{array}{c}\text { Number } \\
\text { of } \\
\text { articles }\end{array}$ & $\begin{array}{c}\text { Percent } \\
\text { of } \\
\text { articles }\end{array}$ \\
\hline \multirow{3}{*}{$\begin{array}{l}\text { Required } \\
\text { resources }\end{array}$} & Required resources addressed & 4 & $20 \%$ \\
\hline & Required resources not addressed & 16 & $80 \%$ \\
\hline & Total number of articles & 20 & $100 \%$ \\
\hline
\end{tabular}

Table 12. Summary of the articles classified according to as-is analysis tools

\begin{tabular}{|c|c|c|c|}
\hline $\begin{array}{c}\text { Coding } \\
\text { dimension }\end{array}$ & Codes & $\begin{array}{c}\text { Number } \\
\text { of } \\
\text { articles }\end{array}$ & $\begin{array}{c}\text { Percent } \\
\text { of } \\
\text { articles }\end{array}$ \\
\hline \multirow{2}{*}{$\begin{array}{c}\text { As-is } \\
\text { analysis } \\
\text { tools }\end{array}$} & As-is analysis tools provided & 5 & $25 \%$ \\
\hline & As-is analysis tools not provided & 15 & $75 \%$ \\
\hline & Total number of articles & 20 & $100 \%$ \\
\hline
\end{tabular}


- for a company analysis based on the customization level and product modularity type [39]; and

- for applying product similarity measures to existing product families [41].

\subsection{Hindrance factors}

The analysis of available MC-IGs shows that:

- Only $15 \%$ of the articles address hindrance factors (Table 13).

- Hindrance factors identified in the MC-IGs are:

- resistance to change from managers and company engineers [37];

- lack of resources [41]; and

- need for additional employee training for $\mathrm{MC}$ [35].

\subsection{Instruction exemplification}

The analysis of available MC-IGs shows that:

- Almost all articles exemplify the implementation instructions they provide (Table 14).

- Examples can be used to (Table 15):

- explain how the enabler should be applied in practice, or

- present an application of the implementation instructions.

- IGs can contain both of the previously stated applications.

\subsection{Instruction format}

Implementation instructions can be provided in the following formats (definitions are taken from Suzić et al. [1, pp.862-863]):

- textual format:

- plain text only - a case when "instructions are presented in a textual format without any structure"; and

- organized text - a case when "instructions are organised using bullet points, paragraphs or sections, where every step provides instruction for a single activity";

- graphical format - a case when "instructions are provided through a graphical presentation, for example, in the form of a flow chart, drawing, chart, diagram, and so on"; and

- tabular format - a case when "instructions are given in the form of a table".

The analysis of available MC-IGs shows that:

- Formats are not mutually exclusive. Thus, one implementation instruction can be provided in multiple formats, leading to a higher total than the recorded number of implementation instructions (Table 16).

- "Single enabler" implementation instructions tend to provide more information per instruction because they tend to be more detailed and elaborate. As a result, "single enabler" implementation instructions use 2 or 3 formats per instruction (2.8 on average) (Table 16).

- "Bundled enabler" implementation instructions are often provided in a very brief form with much less information. As a result, "bundled enabler" implementation instructions use 1 or 2 formats per instruction (1.4 on average) (Table 16).

- For most of the "single enabler" instructions, both plain text (present in $74 \%$ of "single enabler" implementation instructions) and a graphical format $(89 \%)$ are used, with the addition of either organized text $(49 \%)$ or a tabular format $(66 \%)$ (Table 16$)$.

- "Bundled enabler" implementation instructions use plain text (present in $46 \%$ of the "bundled enabler" implementation instructions), organized text (46\%), or a graphical format (47\%), and the 3 couplings of these 3 formats are equally distributed (Table 16).

Table 13. Summary of the articles classified according to hindrance factors

\begin{tabular}{|c|c|c|c|}
\hline $\begin{array}{c}\text { Coding } \\
\text { dimension }\end{array}$ & Codes & $\begin{array}{c}\text { Number } \\
\text { of } \\
\text { articles }\end{array}$ & $\begin{array}{c}\text { Percent } \\
\text { of } \\
\text { articles }\end{array}$ \\
\hline \multirow{3}{*}{$\begin{array}{c}\text { Hindrance } \\
\text { factors }\end{array}$} & Hindrance factors provided & 3 & $15 \%$ \\
\hline & Hindrance factors not provided & 17 & $85 \%$ \\
\hline & Total number of articles & 20 & $100 \%$ \\
\hline
\end{tabular}

Table 14. Summary of the articles classified according to instruction exemplification

\begin{tabular}{|c|l|c|c|}
\hline $\begin{array}{c}\text { Coding } \\
\text { dimension }\end{array}$ & Codes & $\begin{array}{c}\text { Number } \\
\text { of } \\
\text { articles }\end{array}$ & $\begin{array}{c}\text { Percent } \\
\text { of } \\
\text { articles }\end{array}$ \\
\hline $\begin{array}{c}\text { Instruction } \\
\text { exemplifica- } \\
\text { tion }\end{array}$ & $\begin{array}{l}\text { Exemplified implementation } \\
\text { instructions }\end{array}$ & 18 & $90 \%$ \\
\hline $\begin{array}{c}\text { Non-exemplified implementation } \\
\text { instructions }\end{array}$ & 2 & $10 \%$ \\
\hline \multicolumn{2}{|c|}{ Total number of articles } & 20 & $100 \%$ \\
\hline
\end{tabular}

Table 15. Purpose of exemplification in MC-IGs

\begin{tabular}{|c|c|c|c|}
\hline $\begin{array}{l}\text { Coding sub- } \\
\text { dimension }\end{array}$ & Sub-codes & $\begin{array}{c}\text { Number } \\
\text { of } \\
\text { articles }\end{array}$ & $\begin{array}{c}\text { Percent } \\
\text { of } \\
\text { articles }\end{array}$ \\
\hline \multirow{3}{*}{$\begin{array}{l}\text { Exemplified } \\
\text { implementation } \\
\text { instructions } \\
\text { purpose }\end{array}$} & $\begin{array}{l}\text { Explaining how the enabler should } \\
\text { work when applied in practice (a) }\end{array}$ & 1 & $5.6 \%$ \\
\hline & $\begin{array}{l}\text { Example of implementation } \\
\text { instructions application in practice (b) }\end{array}$ & 2 & $11.1 \%$ \\
\hline & $\begin{array}{l}\text { Examples used for both purposes } \\
(\mathrm{a}+\mathrm{b})\end{array}$ & 15 & $83.3 \%$ \\
\hline & Total number of articles & 18 & $100 \%$ \\
\hline
\end{tabular}

Table 16. Analysis of the articles according to instruction format

\begin{tabular}{|c|c|c|c|c|c|c|}
\hline & \multicolumn{2}{|c|}{$\begin{array}{l}\text { "Single enabler" } \\
\text { implementation } \\
\text { instructions }\end{array}$} & \multicolumn{2}{|c|}{$\begin{array}{l}\text { "Bundled enabler" } \\
\text { implementation } \\
\text { instructions } \\
\end{array}$} & \multirow[b]{2}{*}{ Total } \\
\hline $\begin{array}{c}\text { Coding } \\
\text { dimension }\end{array}$ & Codes & $\begin{array}{l}\text { No. of "single } \\
\text { enabler" } \\
\text { implementa- } \\
\text { tion } \\
\text { instructions } \\
\text { provided in a } \\
\text { specific } \\
\text { format }\end{array}$ & $\begin{array}{c}\text { \% from } \\
\text { total of } \\
47 \\
\text { "single } \\
\text { enabler" } \\
\text { impl. } \\
\text { instr. }\end{array}$ & \begin{tabular}{|c|} 
No. of \\
"bundled \\
enabler" \\
implemen- \\
tation \\
instructions \\
provided in \\
a specific \\
format
\end{tabular} & $\begin{array}{c}\text { \% from } \\
\text { total of } \\
59 \\
\text { "bundled } \\
\text { enabler" } \\
\text { impl. } \\
\text { instr. }\end{array}$ & \\
\hline \multirow{4}{*}{$\begin{array}{l}\text { Instruction } \\
\text { format }\end{array}$} & $\begin{array}{l}\text { Plain text } \\
\text { (Textual } \\
\text { format) } \\
\end{array}$ & 35 & $74 \%$ & 27 & $46 \%$ & 62 \\
\hline & \begin{tabular}{|l|} 
Organized \\
text \\
(Textual \\
format) \\
\end{tabular} & 23 & $49 \%$ & 27 & $46 \%$ & 50 \\
\hline & $\begin{array}{l}\begin{array}{l}\text { Graphical } \\
\text { format }\end{array} \\
\end{array}$ & 42 & $89 \%$ & 28 & $47 \%$ & 70 \\
\hline & $\begin{array}{l}\text { Tabular } \\
\text { format }\end{array}$ & 31 & $66 \%$ & 0 & $0 \%$ & 31 \\
\hline \multicolumn{2}{|c|}{$\begin{array}{r}\text { Total number of } \\
\text { cases in which } \\
\text { instructions have } \\
\text { been provided }\end{array}$} & 47 & $100 \%$ & 59 & $100 \%$ & 106 \\
\hline \multicolumn{2}{|c|}{$\begin{array}{r}\text { Average number of } \\
\text { instruction formats } \\
\text { used per instruction }\end{array}$} & 2.8 & - & 1.4 & - & $\mathrm{N} / \mathrm{A}$ \\
\hline
\end{tabular}


- The tabular format is not used for "bundled enabler" implementation instructions (Table 16).

- Use of plain text and organized text is similar in both implementation instruction types, while the use of the graphical format differs, namely:

- in "single enabler" implementation instructions, the graphical format, along with the tabular format, is mainly used to provide sufficiently detailed examples of enabler implementation; while

- for "bundled enabler" implementation instructions, the graphical format is most often used to convey exact relationships between enablers.

\subsection{Research method of MC-IGs}

Relevant articles were analyzed based on the research method they applied to: (1) build the implementation guidelines, and (2) assess the validity of the implementation guidelines (Table 17). An established classification of research methods [52, 53], augmented with the action research method [54], was used to classify the articles as conceptual modeling, case studies (including multiple case studies), surveys, mathematical modeling (or simulation), and action research (Table 17).

The analysis of available MC-IGs shows that:

- Conceptual modeling is the main research method for building MC-IGs (18 articles, 90\%, Table 17).

- Case study is the main research method for assessing the validity of the MC implementation guidelines (14 articles, 70\%, Table 17).

- Only $3(15 \%)$ articles do not perform tests of the developed MC-IGs.

- Deeper analysis of the 18 articles that build IGs through conceptual modeling shows that most of them assess the proposed IGs through case study.

- The 14 articles that report using case studies to assess the validity of MC-IGs, use the term "case study" in a broader sense than it is used in the field of Operations Management (see [55]). While 8 articles (57\% of articles) test the MC-IGs in actual contexts, 5 articles (36\% of articles) simply use real company data to exemplify the application of IGs in a context similar to a real one, and 1 article bases its validity assessment on fictitious data.

- The assessment of MC-IGs through case studies can be characterized based on the number of cases used and on who performs the assessment. Most of the 14 articles that assess the validity of MC-IGs through a case study use a single case study. However, 3 articles use multiple case studies [35, $36,41]$. The situation is more differentiated when we consider who performs the testing in a real organization (8 of 14 articles). In this case, $50 \%$ of the articles report that testing was done by the authors themselves, while the rest of the articles $(50 \%)$ do not report who did the testing of the implementation guidelines. Interestingly, none of the articles reported that the MC-IGs were tested by the company personnel with researchers involved as no more than external observers.

- Only 2 articles use a method different from conceptual modeling for developing MC-IGs (Table 17). Yang et
Table 17. Summary of articles according to research method (RM)

\begin{tabular}{|l|c|c|c|c|c|c|c|}
$\begin{array}{l}\text { RM to assess } \\
\text { the IGs }\end{array}$ & $\begin{array}{c}\text { Conc. } \\
\text { model. }\end{array}$ & $\begin{array}{c}\text { Case } \\
\text { study }\end{array}$ & Survey & $\begin{array}{c}\text { Math } \\
\text { (or } \\
\text { buimul.) }\end{array}$ & $\begin{array}{l}\text { Action } \\
\text { research }\end{array}$ & $\begin{array}{c}\text { Not } \\
\text { tested }\end{array}$ & $\begin{array}{c}\text { Total } \\
\text { (percent) }\end{array}$ \\
\hline $\begin{array}{l}\text { Conceptual } \\
\text { modeling }\end{array}$ & 0 & 13 & 0 & 2 & 0 & 3 & $\begin{array}{c}18 \\
(90 \%)\end{array}$ \\
\hline Case study & 0 & 1 & 0 & 0 & 0 & 0 & $1(5 \%)$ \\
\hline Survey & 0 & 0 & 0 & 0 & 0 & 0 & $0(0 \%)$ \\
\hline $\begin{array}{l}\text { Math } \\
\text { (or simul.) }\end{array}$ & 0 & 0 & 0 & 0 & 0 & 0 & $0(0 \%)$ \\
\hline Action research & 0 & 0 & 0 & 0 & 1 & 0 & $1(5 \%)$ \\
\hline Total (percent) & $\begin{array}{c}10 \%) \\
(0 \%)\end{array}$ & $\begin{array}{c}14 \\
(70 \%)\end{array}$ & $\begin{array}{c}0 \\
(0 \%)\end{array}$ & $\begin{array}{c}1 \\
(10 \%)\end{array}$ & $\begin{array}{c}1 \\
(5 \%)\end{array}$ & $\begin{array}{c}20 \\
(15 \%)\end{array}$ \\
$(100 \%)$ \\
\hline
\end{tabular}

al. [24] use the case study method for building and testing implementation guidelines at the same time, while Kudsk, Hvam et al. [37] use action research to build and assess the implementation guidelines.

\section{DISCUSSION}

This section discusses the results of the present research. It does so by describing opportunities for further improvement in the content and presentation of MC-IGs as well as MC-IG development and assessment methods and by discussing the contribution of the present research with respect to previous $\mathrm{MC}$ literature reviews.

\subsection{MC-IG content and presentation}

This sub-section discusses the findings presented in the Results section. It does so by providing a synthesis of the findings for each of the classification dimensions that address MC-IG contents and presentation (i.e., the first 8 classification dimensions) (Table 5 ), as well as by specifying opportunities for further research, improvement of MC-IGs, and contributions to the MC-IG research sub-stream.

MC overview - Results of the analysis show that only 4 out of 20 articles contain an overview of MC (Table 6). So, the presence of an MC overview is limited in the relevant articles. Among the possible reasons for the limited presence of MC overviews we can mention the considerable effort required to develop a synthetic and exhaustive overview on the one hand and, on the other hand, the possibility that researchers feel it has already been done by someone else. No matter what the reason might be, MC overviews should be included in future developed MC-IGs because otherwise these guidelines would lack a part important for practitioners [1].

Specifically, an MC overview should ideally include all MC overview essentials. This information enables practitioners to understand the main characteristics of $\mathrm{MC}$ and the position of MC among other manufacturing strategies (e.g., mass production, custom manufacturing, etc.) and to make a first assessment of their own company's position with regard to MC.

MC implementation instructions can be:

- "Single enabler" implementation instructions, which are crucial for practitioners because they save time and effort in the implementation steps elaboration. This is because "single enabler" implementation instructions are detailed and thus require less work of practitioners in the 
- elaboration and specification of enabler implementation.

"Single enabler" implementation instructions are present in the majority of the relevant papers (19 out of 20, Table 8). At first glance, this is a good result of the research, but the analysis also showed that altogether 8 enablers were recorded (Table 7 ), with the most usual case covering 2 or 3 enablers in one article (Table 8). We argue that this narrow research scope is usually a consequence of researchers' previous experiences and opinions regarding the most important enablers for MC implementation. We conclude that widening the scope of the enablers addressed in future developed MC-IGs should be set as a goal.

- "Bundled enabler" implementation instructions, which are important for practitioners because they reduce the efforts required for $M C$ implementation planning. Thus, these instructions can be used as an $\mathrm{MC}$ implementation plan, or part of one, by practitioners who can implement them as given or with some modifications.

"Bundled enabler" implementation instructions are present in all relevant articles (Table 9). This is good coverage, but deeper analysis shows that many of these instructions are provided mainly for a limited number of enablers - usually 2 or 3 (17 out of 20 articles, Table 9 ). Analysis also showed that these instructions are often implicitly given (4 out of 20 , Table 9). We recommend that "bundled enabler" implementation instructions should include more enablers and should be given explicitly in future developed MC-IGs.

Applicability context of the guidelines - Results show that only 7 out of 20 articles provide an explicit applicability context (Table 10). Thus, the presence of applicability context is limited in the relevant papers. Perhaps, some researchers do not find it necessary to list the applicability context, assuming that the nature of the examples they provide implicitly communicates the applicability context (Table 10). Listing and justifying the applicability context should be a characteristic of future developed MC-IGs.

While our research has shown that MC-IGs could be improved by stating their applicability context, further development of the implementation guidelines will probably require that they be developed with a specific context in mind (e.g., SMEs, furniture industry, etc.). This viewpoint is further supported by Sousa and Voss [56, p.711], who state that "the failure to acknowledge the limits of applicability of OM practices may lead to their application in contexts to which they are not suitable." For example, the degree of product customization [57] is a crucial contingency variable that moderates the impact of organization-level enablers on MC capability (e.g., [58, 59]) and, therefore, should be considered in the development of MC-IGs. Moreover, some of the questions to be considered related to the applicability context of the guidelines are: Which components of the IGs are context dependent and which are not? What are the characteristics of the context that are relevant for IG development and utilization (e.g., degree of product customization, industry, service-manufacturing distinction, company size, etc.)? Which context variables are relevant for tailoring the IGs for each case of MC implementation? Required resources - Unfortunately, only a minority of articles consider required resources for MC implementation (4 out of 20 articles, Table 11). Required resources, instead, should receive more attention in the future developed MC-IGs because the unavailability of required resources may undermine the success of MC implementation.

Furthermore, we found that the few articles covering the required resources lack of systematicity in addressing this issue. There is no taxonomy of resources that has been used so far in the MC-IG research sub-stream.

As-is analysis tools - Only 5 out of 20 articles propose as-is analysis tools for MC implementation (Table 12). Thus, there is a limited presence of as-is analysis tools in the relevant articles. This absence of as-is analysis tools could be due to the implicit assumption that the initial company situation is that one of mass production. This implicit assumption is aligned with the prevalent perspective of $\mathrm{MC}$ research that see $\mathrm{MC}$ implementation as transformation from mass production to MC. Nevertheless, it is likely that most of the companies moving towards MC will not start from pure mass production but will be somewhere between mass production and $\mathrm{MC}$, or between custom manufacturing and $\mathrm{MC}$ [60]. Consequently, the initial situation should be assessed and not be taken for granted, thus as-is analysis tools should be provided for the future developed MC-IGs.

Additionally, the research has shown that as-is analysis tools can vary substantially in different MC-IGs. In future research, the $\mathrm{MC}-\mathrm{IG}$ research sub-stream could benefit from a comprehensive classification of the as-is analysis tools that are used. For example, a distinction could be made between the as-is analysis tools that are applied very quickly, providing an overall view of the company with regard to MC, and tools that are very detailed. These detailed as-is analysis tools could eventually help to determine the scope and pace of implementation of $\mathrm{MC}$ enablers.

Hindrance factors - Only 3 out of 20 articles provide hindrance factors (Table 13). Thus, we observe a limited presence of hindrance factors in the relevant articles. Focusing on how to do something as opposed to what hinders doing it may be understandable. Nevertheless, knowing the hindrance factors in advance is obviously useful for MC implementation and, consequently, hindrance factors should be included as part of the future developed MC-IGs.

Furthermore, although hindrance factors have been considered in some articles, there are still a number of open questions; for example: What are the hindrance factors? Are some hindrance factors interdependent? Are hindrance factors context dependent? Are hindrance factors related to the available and required resources? Are hindrance factors common across the different MC enablers? What is the different impact of different hindrance factors importance? A further open issue concerns indications of how to identify company-specific 
hindrance factors and how to mitigate the influence of the hindrance factors.

Instruction exemplification - Instruction exemplification is provided in 18 of 20 articles (Table 14). This represents high coverage in the relevant articles. We argue that this is due to the nature of knowledge transfer, where conveying ideas is more effective if an example is provided. We conclude that the need to provide examples for implementation instructions has been recognized by researchers and is fulfilled in the relevant articles.

Instruction format - Instruction formats are used in different proportions depending on the instruction contents. "Single enabler" implementation instructions have high use of plain text (35 out of 47 , Table 16) and graphical format (42 out of 47, Table 16). "Bundled enabler" implementation instructions have relatively high use of plain text (27 of 59, Table 16), organized text (27 of 59 , Table 16), and graphical format (28 of 59, Table 16) but do not use the tabular format (Table 16). We argue that it is easier to provide instructions through plain text than through organized text, graphical or tabular formats. However, our experience has shown that the plain text instruction format takes more time to be processed and generates more interpretation disagreements among readers than the other 3 instruction formats used in MC-IGs (i.e., organized text, graphical format, and tabular format). These findings imply that the communication effectiveness of the plain text format is lower than that of the other 3 identified instruction formats. Thus, we conclude that future developed MC-IGs should limit the use of the plain text format where possible. In other words, the integrated use of organized text, graphical formats, and tabular formats should be preferred over the use of the plain text format in future developed MC-IGs.

\subsection{MC-IG development and assessment methods}

The present literature review showed that the research method most frequently used for building MC-IGs is conceptual modeling (18 out of 20 reviewed articles, Table 17), and the research method most frequently used for assessing the validity of IGs is the case study (14 out of 20 reviewed articles, Table 17). The extensive use of conceptual modeling for building MC-IGs (Table 17) shows that researchers ground their newly developed IGs within existing academic knowledge. The extensive use of the case study method to assess the validity of MC-IGs (Table 17) shows an intention of researchers to guarantee that the proposed MC-IGs actually work in practice. This evidence and these considerations lead us to conclude that MC-IG research strives to integrate academia and practice.

The research methods used to develop MC-IGs and assess their validity play an important role in obtaining acceptance and trust from practitioners. More acceptable and effective MC-IGs can be developed by improving and innovating the research methods used to develop them. Among others, interviews with practitioners (consultants, managers, and entrepreneurs) could be used in order to better understand the impact of a specific industry context, company size, and so on, which should be taken into account when developing MC-IGs. Focus groups with $\mathrm{MC}$ consultants could be a method to build on the failures and successes accumulated through years of implementation experiences in different contexts. Furthermore, longitudinal observations could be used to assess the long-term effect of MC-IG use and could generate specific refinements based on practical experiences of MC implementation.

One peculiar aspect of MC-IG research pertains to the research strategy it adopts. We think that MC-IG research naturally fits with a design science research (DSR) strategy. A DSR strategy aims to develop knowledge that can be used in a specific and direct way to design and implement actions, processes, or systems to achieve desired outcomes in practice [61]. The development of the knowledge to guide the successful implementation of MC initiatives can be seen as a specific case of a DSR strategy.

Design science research differs from explanatory science research, as the latter develops knowledge to describe, explain, and predict observable phenomena [62]. While most of the MC research is focused on describing what $M C$ is and how the various $M C$ practices/enablers contribute to obtaining MC capability, the MC-IG research stream is focused on developing valid and reliable knowledge to be used in designing solutions to the problem of MC implementation. Therefore, MC-IG researchers, when developing their IGs, should consider the adoption of a DSR strategy because their research is, as a matter of fact, an instance of DSR (cf. [62]).

Notably, recently, the DSR strategy has increasingly drawn the attention of Management and in particular Operations Management researchers. This trend can be clearly seen in the increase in the number of articles using DSR strategy published in recent years. Specifically, a search with the term "design science research" in Article Title, Abstract, and Keywords in the Scopus database (limited to English language and the subject areas of "Business, management, and accounting" and "Decision sciences") in November of 2018 yielded 129 articles. Notably, 85 (65.9\%) of these 129 articles have been published in the last 5 years. Moreover, the Journal of Operations Management, ${ }^{*}$ a reference journal in the field of Operations Management, recognized this trend by inaugurating its Design Science Department in 2016 and by stating that "the fundamental idea of the [Design Science] department is to promote work where the researcher does not merely observe, but actually becomes a problem solver, typically in collaboration with the practitioner." $\dagger$ This increased interest and recognition of the DSR strategy in the Operations Management field makes research on MC-

\footnotetext{
* https://www.journals.elsevier.com/journal-of-operationsmanagement/
}

\footnotetext{
$\dagger$ The citation is taken from the e-mail announcing the new Design Science Department of the Journal of Operations Management (March 2017).
} 
IGs more welcome in OM journals if it is framed using such a strategy. In particular, by stating upfront that an MC-IG article is using a DSR strategy, it will be easier for an OM scholar accustomed to reading explanatory research to understand the purpose of the cases reported in an MC-IG article.

\subsection{A contribution with respect to the previous MC literature reviews}

This section discusses the contribution of the present research with respect to previous $\mathrm{MC}$ literature reviews. Firstly, we discuss the contribution of the present research relative to the literature review presented in Suzić et al. [1]. Secondly, we discuss the contribution of the present research with respect to other MC literature reviews [2, 6-9].

Firstly, the present work, built upon the research presented in Suzić et al. [1], contributes to the further development of the MC-IG sub-stream by helping researchers frame and develop their MC-IGs. This is achieved by providing a detailed analysis of how MC-IG research is done and communicated. In this way, the present research complements Suzić et al. [1], who focused on practitioners by identifying the characteristics of available MC-IGs and generating suggestions for increasing their usefulness for practitioners.

Secondly, our literature review complements other previously conducted literature reviews on MC. Altogether, 5 other literature review articles that focus on MC were found [2, 6-9]. Three of these 5 literature reviews cover overall $\mathrm{MC}$ [6-8], while 2 of these reviews focus on a specific part of the MC research [2, 9]. None of the 5 literature reviews focuses on $\mathrm{MC}$ implementation or MC-IGs.

The first article with overall coverage-da Silveira, Borenstein, and Fogliatto [6]—-classified the available MC frameworks, discussed MC success factors and $M C$ enablers, and provided a general MC research agenda for the future. A decade later, the same group of authors reviewed the $\mathrm{MC}$ literature with a similar focus [8]. In their second literature review, they covered the years 20002010, updating their previous research, and once more identified research gaps for the future. Kumar, Gattoufi, and Reisman [7] provided a literature review with a historical perspective to understand the evolution of $M C$ and $M C$ research and stressed the need to classify $M C$ research.

The two literature reviews that cover a narrower $\mathrm{MC}$ scope differ with regard to their focus. Sandrin, Trentin, and Forza [2] focus their research on MC organizational antecedents. Ferguson, Olewnik, and Cormier [9], instead, focus on the process of MC product development, which they analyze through the lenses of the marketing, engineering, and distribution domains. Both Sandrin, Trentin, and Forza [2] and Ferguson, Olewnik, and Cormier [9] highlight future opportunities for research in their respective topics.

Even though the available literature reviews do not focus on the MC implementation process, they stress the importance of conducting research on this subject. When providing future directions for $\mathrm{MC}$ research, da Silveira, Borenstein, and Fogliatto [6, p.8] call for research on MC implementation, stating that: "Future research on $\mathrm{MC}$ should focus on the formulation of methodologies that enable rapid reconfiguration of existing organizational structures and processes into a mass-customized production system." Although in their latter review, Fogliatto, da Silveira, and Borenstein [8, p.22] do not restate the need for developing MC methodologies, they mention the issue of developing "more effective solutions" compared to existing MC approaches, tangentially touching on the point of MC-IGs. Sandrin, Trentin, and Forza [2, p.159] stress that: "The importance of transforming organizations to pursue an MC strategy has been acknowledged since the introduction of the MC concept." This idea of transforming organizations to pursue an MC strategy is synonymous with the MC implementation process. Our research adds to these literature reviews by providing a quantitatively detailed overview of the MC-IGs available in the MC literature.

Finally, previous literature reviews highlight that research on the MC implementation process is limited. Da Silveira, Borenstein, and Fogliatto [6, p.11] conclude that: "there are several pending issues regarding its [mass customization's] practical implementation" and that "literature on MC implementation is still incipient." They base these conclusions on the fact that "Most claims are drawn from limited case examples or based on educated guesses from authors rather than from hard evidence obtained through exhaustive research" [6, p.11], then they are calling for large scale studies. Kumar, Gattoufi, and Reisman [7, p.653] assert that "there is a void of rigorous quantitative modeling and decision support in implementing mass customization strategy successfully and effectively," which supports the point that research on MC implementation is limited. These conclusions are in line with our research findings, which highlighted the relatively low number of articles retrieved from the MC literature that could be characterized as MCIGs (20 articles).

\section{CONCLUSIONS}

The present literature review complements the previous $M C$ literature reviews that cover either overall MC research [6-8] or focus on a specific part of the MC research $[1,2,9]$. These reviews stress the importance of conducting research on $\mathrm{MC}$ implementation $[2,6,8]$ and, in particular, on MC-IGs [1]. They also highlight that research on the $\mathrm{MC}$ implementation process has been limited [1, 6, 7]. However, only Suzić et al. [1] literature review focuses on $M C$ implementation and, more precisely, on the guidelines for implementing MC, taking the point of view of practitioners.

The present literature review complements that of Suzić et al. [1], taking the point of view of researchers. Having analyzed the same set of articles and having used the same method, the present research suffers the same limitation as Suzić et al.'s [1], that is, the search for MCIG articles was restricted to the top-ranking (Q1 and Q2) journals in Scopus/Scimago. Regarding the present paper's contribution, it makes three main contributions that complement Suzić et al. [1] contributions. First, it suggests the adoption of the design science research strategy to raise the quality and increase the recognition of the MC-IG research sub-stream. Second, it provides all the quantitative details resulting from the content 
analysis of the reviewed articles to help researchers in positioning new MC-IG articles. Third, it provides all the possible details on the method followed in performing the systematic literature review to further facilitate researchers to replicate it precisely.

Regarding the first contribution, this article recognizes the DSR strategy as appropriate for MC-IG research. Interestingly, none of the MC-IG articles reviewed mentions DSR, although their intended objectives are consistent with those of DSR strategy. We suggest open and wide adoption of the DSR strategy for future development of MC-IGs. Since most of the journals where MC-IGs have been published are journals with an engineering background, an article framed in this way should be welcome. Furthermore, DSR is receiving increasing consideration in Management journals and, in particular, in Operations Management journals. The quality of MC-IGs should benefit from the adoption of a DSR strategy because it can help MC-IG researchers determine a clearer position with regard to their intended contribution. Researchers do not have to use new methods at the operational level, since "there are, in principle, no differences at the tactical level of methods for data gathering and data analysis; DSR does not need specific methods at this tactical level" [61, p.8]. Therefore, DSR, with its increasing academic acceptance and its capability to obtain pragmatic results, offers an opportunity to improve both MC-IG research quality and academic recognition.

Regarding the second contribution, this article reports all the quantitative details resulting from the content analysis of the reviewed articles. It provides an exhaustive picture of what prior research has accomplished, thus helping researchers identify gaps and associated opportunities for future research. This will help researchers to better design their research and communicate their contribution.

Concerning the third contribution, being oriented to researchers, this article uses more space to report all of the details of the method followed in performing the systematic literature review. The process of inductively developing the coding scheme as well as the coding scheme itself have been reported in detail. While all of this information is of secondary importance or could even be confusing for practitioners, it is of crucial importance for researchers. Researchers may be willing to replicate the research or, more likely, to conduct the same research not only updating it with newly published articles, but also considering a wider coverage of journals. For such researchers it is important to have all relevant details in order to compare their results with those reported in the present article and to be sure that eventual differences do not depend on different modalities in conducting the literature review.

These three researcher-oriented contributions will hopefully help raise the quality and the standing of MCIG research, facilitating researchers in their research and publication efforts. Together with Suzić et al.'s [1] article, the present one sets the stage for MC-IG research and favor the recognition of MC-IGs as an MC research substream with a distinct objective, a distinct research strategy, and a reference structure on which to base future enhancements of MC-IGs.

\section{ACKNOWLEDGEMENTS}

We acknowledge financial support from the University of Padova, project ID: BIRD172577.

\section{REFERENCES}

[1] Suzić, N., Forza, C., Trentin, A. and Anišić, Z. (2018), "Implementation guidelines for mass customization: Current characteristics and suggestions for improvement", Production Planning \& Control, Vol. 29, No. 10, pp. 856-871.

[2] Sandrin, E., Trentin, A. and Forza, C. (2014), "Organizing for mass customization: Literature review and research agenda", International Journal of Industrial Engineering and Management, Vol. 5, No. 4, pp. 159-167.

[3] Pine, J. B. (1993), Mass Customization: The New Frontier in Business Competition, Harvard Business School Press, Boston, USA.

[4] Liu, G., Shah, R. and Schroeder, R. G. (2006), "Linking work design to mass customization: A sociotechnical systems perspective", Decision Sciences, Vol. 37, No. 4, pp. 519-545.

[5] Squire, B., Brown, S., Readman, J. and Bessant, J. (2006),"The impact of mass customisation on manufacturing trade-offs", Production and Operations Management, Vol. 15, No. 1, pp. 10-21.

[6] da Silveira, G., Borenstein, D. and Fogliatto, F. S. (2001), "Mass customization: Literature review and research directions", International journal of Production Economics, Vol. 72, No. 1, pp. 1-13.

[7] Kumar, A., Gattoufi, S. and Reisman, A. (2007), "Mass customization research: trends, directions, diffusion intensity, and taxonomic frameworks", International Journal of Flexible Manufacturing Systems, Vol. 19, No. 4, pp. 637-665.

[8] Fogliatto, F. S., da Silveira, G. J. C. and Borenstein, D. (2012), "The mass customization decade: An updated review of the literature", International Journal of Production Economics, Vol. 138, No. 1, pp. 14-25.

[9] Ferguson, S. M., Olewnik, A. T. and Cormier, P. (2014), "A review of mass customization across marketing, engineering and distribution domains toward development of a process framework", Research in Engineering Design, Vol. 25, No. 1, pp. 11-30.

[10] Hart, C. W. L. (1995), "Mass customization: Conceptual underpinnings, opportunities and limits," International Journal of Service Industry Management, Vol. 6, No. 2, pp. 36-45.

[11] Rowley, J. and Slack, F. (2004), "Conducting a literature review", Management Research News, Vol. 27, No. 6, pp. 31-39.

[12] Tranfield, D., Denyer, D. and Smart, P. (2003), "Towards a methodology for developing evidence-informed management knowledge by means of systematic review", British Journal of Management, Vol. 14, No. 3, pp. 207-222.

[13] Seuring, S. and Gold, S. (2012), "Conducting content-analysis based literature reviews in supply chain management", Supply Chain Management: An International Journal, Vol. 17, No. 5, pp. 544-555.

[14] Ortiz, A., Lario, F. and Ros, L. (1999), "Enterprise Integrationbusiness processes integrated management: A proposal for a methodology to develop enterprise integration programs", Computers in Industry, Vol. 40, No. 2-3, pp. 155-171.

[15] Rouhani, B. D., Mahrin, M. N., Nikpay, F., Ahmad, R. B. and Nikfard, P. (2015), "A systematic literature review on enterprise architecture implementation methodologies", Information and Software Technology, Vol. 62, No. 1, pp. 1-20.

[16] Daaboul, J., Bernard, A. and Laroche, F. (2012), "Extended value network modelling and simulation for mass customization implementation", Journal of Intelligent Manufacturing, Vol. 23, No. 6, pp. 2427-2439.

[17] Purohit, J. K., Mittal, M. L., Mittal, and Sharma, M. K. (2016), "Interpretive structural modeling-based framework for mass customisation enablers: An Indian footwear case", Production Planning \& Control, Vol. 27, No. 9, pp. 774-786.

[18] Ma, S., Wang, W. and Liu, L. (2002), "Commonality and postponement in multistage assembly systems", European Journal of Operational Research, Vol. 142, No. 3, pp. 523-538.

[19] Salvador, F., Forza, C. and Rungtusanatham, M. (2002), "Modularity, product variety, production volume, and component 
sourcing: Theorizing beyond generic prescriptions", Journal of Operations Management, Vol. 20, No. 5, pp. 549-575.

[20] Hernandez, G., Allen, J. K. and Mistree, F. (2003), "Platform design for customizable products as a problem of access in a geometric space", Engineering Optimization, Vol. 35, No. 3, pp. 229-254.

[21] Piller, F. T., Moeslein, K. and Stotko, C. M. (2004), "Does mass customization pay? An economic approach to evaluate custome integration", Production Planning \& Control, Vol. 15, No. 4, pp. 435-444.

[22] Blecker, T. and Abdelkafi, N. (2006), "Complexity and variety in mass customization systems: analysis and recommendations", Management Decision, Vol. 44, No. 7, pp. 908-929.

[23] Krishnapillai, R. and Zeid, A. (2006), "Mapping product design specification for mass customization", Journal of Intelligent Manufacturing, Vol. 17, No. 1, pp. 29-43.

[24] Yang, Q. H., Qi, G. N., Lu, Y. J. and Gu, X. J. (2007), “Applying mass customization to the production of industrial steam turbines", International Journal of Computer Integrated Manufacturing, Vol. 20, No. 2-3, pp. 178-188.

[25] Shamsuzzoha, A., Kyllönen, S. and Helo, P. (2009), "Collaborative customized product development framework," Industrial Management \& Data Systems, Vol. 109, No. 5, pp. 718-735.

[26] Feitzinger, E. and Lee, H. (1997), "Mass customization at HewlettPackard: the power of postponement", Harvard Business Review, Vol. 75, No. 1, pp. 116-121.

[27] Jiao, J., Zhang, L. and Pokharel, S. (2005), "Coordinating product and process variety for mass customized order fulfilment", Production Planning \& Control, Vol. 16, No. 6, pp. 608-620.

[28] Thomas, D. R. (2006), "A general inductive approach for analyzing qualitative evaluation data", American Journal of Evaluation, Vol. 27, No. 2, pp. 237-246.

[29] Weiskopf, N. G. and Weng, C. (2013), "Methods and dimensions of electronic health record data quality assessment: enabling reuse for clinical research", Journal of the American Medical Informatics Association: JAMIA, Vol. 20, No. 1, pp. 144-51.

[30] Couture, V., Drouin, R., Tan, S.-L., Moutquin, J.-M. and Bouffard, C. (2015), "Cross-border reprogenetic services", Clinical genetics, Vol. 87, No. 1, pp. 1-10

[31] Harvey, J., Dopson, S., McManus, R. J. and Powell, J. (2015), "Factors influencing the adoption of self-management solutions. an interpretive synthesis of the literature on stakeholde experiences", Implementation science: IS, Vol. 10, No. 1, p. Article number 159.

[32] Thuan, N. H., Antunes, P. and Johnstone, D. (2015), "Factors influencing the decision to crowdsource: A systematic literature review," Information Systems Frontiers, Vol. 18, No. 1, pp. 47-68.

[33] Wood, M. S. and Mckelvie, A. (2015), "Opportunity evaluation as future focused cognition: Identifying conceptual themes and empirical trends", International Journal of Management Reviews, Vol. 17, No. 2, pp. 256-277.

[34] Gao, F., Zhang, Y. and Xiao, G. (2013), "A methodology to support platform parameters determination through considering main factors in product life cycle", International Journal of Computer Integrated Manufacturing, Vol. 27, No. 5, pp. 470-478.

[35] Hanafy, M. and ElMaraghy, H. (2015), "A modular product multiplatform configuration model', International Journal of Computer Integrated Manufacturing, Vol. 28, No. 9, pp. 999-1014

[36] Kudsk, A., Grønvold, M. O., Olsen, M. H., Hvam, L. and Thuesen C. (2013), "Stepwise modularization in the construction industry using a bottom-up approach", The Open Construction and Building Technology Journal, Vol. 7, pp. 99-107.

[37] Kudsk, A., Hvam, L., Thuesen, C., Grønvold, M. O. and Olsen, M. $\mathrm{H}$. (2013), "Modularization in the construction industry using a top down approach", Open Construction and Building Technology Journal, Vol. 7, pp. 88-98.

[38] Zha, X. F., Sriram, R. D., and Lu, W. F. (2004), "Evaluation and selection in product design for mass customization: A knowledge decision support approach", AI EDAM, Vol. 18, No. 01, pp. 87-109.

[39] Salvador, F., Forza, C. and Rungtusanatham, M. (2002), "How to mass customize: Product architectures, sourcing configurations", Business Horizons, Vol. 45, No. 4, pp. 61-69.

[40] Kong, F. B., Ming, X. G., Wang, L., Wang, X. H. and Wang, P. P. (2009), "On modular products development", Concurrent Engineering, Vol. 17, No. 4, pp. 291-300

[41] Ismail, H., Reid, I., Mooney, J., Poolton, J. and Arokiam, I. (2007), "How small and medium enterprises effectively participate in the mass customization game", IEEE Transactions on Engineering Management, Vol. 54, No. 1, pp. 86-97.
[42] Moon, S. K., Shu, J., Simpson, T. W. and Kumara, S. R. T. (2010) "A module-based service model for mass customization: service family design", IIE Transactions, Vol. 43, No. 3, pp. 153-163.

[43] Qu, T., Bin, S., Huang, G. Q. and Yang, H. D. (2011), "Two-stage product platform development for mass customisation", International Journal of Production Research, Vol. 49, No. 8, pp. 2197-2219.

[44] Bajaras, M. and Agard, B. (2014), "A methodology to form families of products by applying fuzzy logic", International Journal on Interactive Design and Manufacturing (IJIDeM), Vol. 9, No. 4, pp. 253-267.

[45] Jiao, J. and Tseng, M. (1999), “A methodology of developing product family architecture for mass customization", Journal of Intelligent Manufacturing, Vol. 10, No. 1, pp. 3-20.

[46] Moon, S. K. and McAdams, D. A. (2012), "A market-based design strategy for a universal product family", Journal of Mechanical Design, Vol. 134, No. 11, p. 111007.

[47] Anišić, Z. and Krsmanović, C. (2008), "Assembly initiated production as a prerequisite for mass customization and effective manufacturing", Strojniski Vestnik/Journal of Mechanical Engineering, Vol. 54, No. 9, pp. 607-618.

[48] Alsawalqah, H. I., Kang, S. and Lee, J. (2014), "A method to optimize the scope of a software product platform based on end-user features", Journal of Systems and Software, Vol. 98, pp. 79-106.

[49] Gao, F., Xiao, G. and Simpson, T. W. (2009), "Module-scalebased product platform planning", Research in Engineering Design, Vol. 20, No. 2, pp. 129-141.

[50] Meng, X., Jiang, Z. and Huang, G. (2006),"On the module identification for product family development", The International Journal of Advanced Manufacturing Technology, Vol. 35, No. 12, pp. 26-40.

[51] Creswell, J. W. (2002), Educational research: Planning conducting, and evaluating quantitative, Prentice Hall, Saddle River, NJ, USA.

[52] Chen, L., Olhager, J. and Tang, O. (2014), "Manufacturing facility location and sustainability: $A$ literature review and research agenda", International Journal of Production Economics, Vol. 149, pp. 154-163.

[53] Pashaei, S. and Olhager, J. (2015), "Product architecture and supply chain design: A systematic review and research agenda" Supply Chain Management: An International Journal, Vol. 20, No. 1, pp. 98-112.

[54] Coughlan, P. and Coghlan, D. (2008), "Action research", in Researching Operations Management, pp. 236-264, New York/London, Routledge.

[55] Voss, C., Tsikriktsis, N. and Frohlich, M. (2002), "Case research in operations management", International Journal of Operations \& Production Management, Vol. 22, No. 2, pp. 195-219.

[56] Sousa, R. and Voss, C. (2008), "Contingency research in operations management practices", Journal of Operations Management, Vol. 26, No. 6, pp. 697-713.

[57] Sandrin, E. (2016), "An empirical study of the external environmental factors influencing the degree of product customization", International Journal of Industrial Engineering and Management, Vol. 7, No. 4, pp. 135-142

[58] Huang, X., Kristal, M. M. and Schroeder, R. G. (2010), "The impact of organizational structure on mass customization capability: A contingency view", Production and Operations Management, Vol. 19, No. 5, pp. 515-530.

[59] Sandrin, E., Trentin, A. and Forza, C. (2018), "Leveraging high involvement practices to develop mass customization capability: A contingent configurational perspective", International Journal of Production Economics, Vol. 196, pp. 335-345.

[60] Duray, R. (2002), "Mass customization origins: Mass or custom manufacturing?', International Journal of Operations \& Production Management, Vol. 22, No. 3, pp. 314-328.

[61] van Aken, J., Chandrasekaran, A. and Halman, J. (2016), "Conducting and publishing design science research: Inaugural essay of the design science department of the Journal of Operations Management', Journal of Operations Management, Vol. 47-48, pp. 1-8

[62] van Aken, J. E. (2004) "management research based on the paradigm of the design sciences: The quest for field-tested and grounded technological rules", Journal of Management Studies, Vol. 41, No. 2, pp. 219-246. 


\title{
Smernice za implementaciju kastomizovane industrijske proizvodnje: Iz perspektive istraživača
}

\author{
Nikola Suzić, Enrico Sandrin, Svetlana Suzić, Cipriano Forza, Alessio Trentin, \\ Zoran Anišić
}

Primljen (26.10.2018.); Recenziran (27.11.2018.); Prihvaćen (03.12.2018.)

\begin{abstract}
Apstrakt
Kastomizovana industrijska proizvodnja (MC) dobija konstantnu pažnju i u industriji i u akademskim krugovima. Nedavno su smernice za implementaciju MC-a (MC-IGs) identifikovane kao jedan od pravaca istraživanja u MC-u. Pregledni rad ovog pravca istraživanja, sa pogledom orijentisanim na praksu, objavljen je u tekućoj godini. Ovaj rad dopunjuje taj pregled fokusiranjem na istraživače i njihovu potrebu da poboljšaju način razvoja i predstavljanja smernica za implementaciju kastomizovane industrijske proizvodnje. Predstavljanjem podataka dobijenih iz sistematskog pregleda literature smernica za implementaciju kastomizovane industrijske proizvodnje, ovaj rad informiše istraživače koliko su i na koji način određeni aspekti MC-IG razmatrani u postojećim smernicama. Kroz sistematski i detaljan opis objavljenih smernica, ovaj rad pruža podršku istraživačima da jasno predstave sličnosti i razlike u njihovim predlozima unapređenja MC-IG smernica. Konačno, uzimajući u obzir samu prirodu rezultata MCIG istraživanja, ovaj rad predlaže sveobuhvatno usvajanje istraživačke strategije design science-a za razvoj $i$ testiranje smernica za implementaciju kastomizovane industrijske proizvodnje.
\end{abstract}

Ključne reči: Kastomizovana industrijska proizvodnja, smernice za implementaciju, pregled literature, platforma proizvoda, modularnost, grupna tehnologija, standardizacija delova, odložena realizacija forme proizvoda, konkurentno inženjerstvo proizvod-proces-lanac snabdevanja, konfiguracija proizvoda, design science istraživanje 